\title{
Management Practice and Contributing Risk
}

\section{Factors for Chronic Complications Among Type 2 Diabetes Mellitus Adult Patients in Follow-Up at a Tertiary Care Teaching Hospital}

This article was published in the following Dove Press journal:

Diabetes, Metabolic Syndrome and Obesity: Targets and Therapy

\section{Zenebe Negash (iD \\ Malede Yismaw (D)}

Department of Pharmacology and Clinical Pharmacy, School of Pharmacy, College of Health Sciences, Addis Ababa University, Addis Ababa, Ethiopia
Correspondence: Zenebe Negash Department of Pharmacology and Clinical Pharmacy, School of Pharmacy, College of Health Sciences, Addis Ababa University, Zambia Street, PO Box 9086, Addis

Ababa, Ethiopia

Tel +25। 931726546

Email zenebe.negash@aau.edu.et
Background: Diabetes Mellitus is a complex, chronic disease that requires a coordinated management practice beyond blood glucose control. The disease causes chronic complications that affect the quality of the life of patients, place major pressure on the health-care system and cause a rise in diabetes-related mortality.

Objective: To determine the prevalence of chronic diabetes mellitus complications, related risk factors, and management practice among adult type 2 diabetes mellitus outpatients at Tikur Anbessa Specialized Hospital (TASH).

Methods: A cross-sectional study design was carried out from July to September 2018. The pre-tested data abstraction format was used to gather demographic and clinical information. We also used a balance of weight measurement, upright placed meter for height measurement, waist circumference measurement meter and BP equipment. Statistical analysis was accomplished using Statistical Package for the Social Sciences (SPSS) $25^{\circledR}$ software. The significance level for statistics was set at $\mathrm{p}<0.05$.

Results: In this study, 320 patients were involved. Of these, about $57 \%$ were female and had a mean age of $58 \pm 11.2$ years. About $85 \%$ of the study participants had comorbidity and $42.5 \%$ had complications. Hypertension and neuropathy were the most common comorbidity and complication, respectively. The usage of vascular preventive medication among study participants was $74.7 \%$ and $55.3 \%$ for statins and ASAs, respectively. Participants in the study who had disease duration of 5-10 years ( $\mathrm{AOR}=3.50,95 \% \mathrm{CI}: 1.19-10.28)$ and fifteen and above ( $\mathrm{AOR}=3.59,95 \% \mathrm{CI}$ : $1.36-9.49)$ were at higher risk of diabetes complication as compared to less than five years.

Conclusion: The prevalence of chronic complications was high among adult T2DM outpatients. The duration of disease and the number of medications used were the factors associated with chronic complications. The use of vascular preventive medications was low among study participants.

Keywords: type $2 \mathrm{DM}$, diabetes complication, risk factors, vascular-preventive medications

\section{Introduction}

Type 2 diabetes mellitus (T2DM) is one of the most common metabolic disorders majorly affecting the adult population. It accounts for $90-95 \%$ of all diabetes cases. $^{1-3}$ Long-term elevations in blood glucose levels contribute to many complications in various organs, including the kidneys, skin, nerves, heart, and blood vessels. $^{4}$ This rise in blood glucose, particularly after diagnosis, is mainly due to 
a lack of compliance with the management plan that involves lifestyle modification and pharmaceutical interventions. 5

One of the main impairment occurring from hyperglycemia is damage to the vasculature. It occurs either at small (microvascular complications) or large blood vessels (macrovascular complications). Diabetic retinopathy is the most common microvascular complication, followed by diabetic nephropathy and neuropathy. All macro-vascular complications arise from the development of atherosclerosis, which gradually causes the narrowing of arterial walls. ${ }^{6,7}$

The diabetes complication is highly prevalent in developing countries such as Sub-Saharan Africans (SSAs), along with an increase in attributing factors. ${ }^{3,8}$ According to the study conducted in Sub-Saharan countries taking the sample from Nigeria, Ghana, and Kenya, hypertension (71\%), erectile dysfunction (35\%), hyperlipidemia (34\%), cataract $(32 \%)$, obesity $(27 \%)$, retinopathy $(15 \%)$, and impaired renal function (13\%) were the most commonly reported complications/comorbidities in T2DM patients. The most common risk factors for the development of complications and comorbidity were duration of T2DM, higher body mass index (BMI), and older age. ${ }^{9}$

A local study conducted at Nedjo general and Nekemte referral hospitals showed that at least one complication of diabetes mellitus occurred in about $1 / 3$ rd of the study participants. The study also showed that the duration of diabetes, patient age, DM regimen, family history of diabetes, and the presence of comorbid medical conditions were positively associated with the occurrence of diabetes complications. In this study, hypertension (41.5\%) was the most reported chronic complications in diabetes patients, followed by visual impairment (20.7\%) and nephropathy (15.9\%). ${ }^{10}$

A better understanding of the burden of diabetes complication among diabetes patients and factors associated with the disease requires important information. It is also necessary recognizing the management strategies practiced as treatment and prevention to prevent immediate and long-term complications, and enhance the patient's quality of life. ${ }^{5}$ Hence, the study was aimed to assess T2DM complications, their management practice, and risk factors attributed to the existence of complications.

\section{Methods}

\section{Study Design and Population}

Hospital-based cross-sectional study design was applied from July to September 2018 for a total of 3 months at the diabetes clinic of Tikur Anbessa Specialized Hospital (TASH), Addis Ababa, Ethiopia, which. TASH is the largest referral hospital in the country that provides a wide-range health-care service for more than 500,000 patients per year. Diabetes clinic is one of the specialty clinics that provide an outpatient service for different endocrine disorders. Adult T2DM patients attend the clinic every Monday and Wednesday based on their appointment. Per annum, more than 6000 patients were attending the diabetes clinic with an average of about 250 patients per week.

All adult type 2 diabetes patients (Age >18years) attending diabetes follow-up clinics of TASH who were diagnosed as DM for at least three months and on at least one medication were included in the study. Severely sick patients who need immediate medical treatment and patients who refuse to join the study were excluded from the study.

\section{Sample Size and Sampling Technique}

A total of 423 sample size were calculated based on single proportion formula assuming a prevalence (p) of 50\% and $10 \%$ contingency (for non-response rate) as there was no research performed on this topic in the setup or the country. During the study period of three months, patients who had an appointment made the sampling frame and the sampling fraction was calculated. The average weekly attender ( $\sim 250$ patients) was used to find a constant (k). During the study period of three months, the clinic provides service for 24 days, and based on this, an average of about 18 patients were sampled every constant $(\mathrm{k}=7)$ each day in a systematic random sampling technique. Then, participant's medical card numbers (ID) were taken every seventh interval for comprehensive chart review and patients' interview.

\section{Data Collection and Management}

Demographic (age, gender, marital status, education, residence, and occupation status) and clinical (comorbidity and complication, duration of the disease, type of medications, source of medication, lifestyle, family history, and physical activity) information was collected using the pre-tested data abstraction format. We had also used weight-measuring balance, height measuring upright positioned meter, waist circumference measuring meter, and blood pressure measuring BP apparatus as data collection tool. For this study, two nurses and two pharmacists were recruited for data collection. They engaged in one-day training to familiarize them with the 
instrument for data collection as well as how to address possible problems encountered during data collection.

A pre-test was performed on five percent of the sample at the diabetes clinic of TASH before data collection started. Based on the results obtained from the pre-test, an amendment was made on the assessment tools and ways of assessment. The training was provided for the data collectors. The principal investigator (PI) was closely supervising the data collection on a daily basis. At the end of each data collection day, the PI checked the completeness of the filled questionnaire and recorded information to ensure its accuracy. After data collection was completed the PI carefully cleaned and entered the data into SPSS. The data analysis was performed with the consultation of a biostatistician.

\section{Data Analysis}

The collected data were evaluated, cleaned, entered, and analyzed using SPSS version 25. Descriptive statistics were computed as frequency, percent, mean and standard deviation (SD) for continuous and categorical variables. Logistic regression tests were performed to determine the relationship of independent variables with diabetes complications in type 2 diabetes patients and to examine possible confounders. Binary logistic regression was performed with $\mathrm{p}$-value $<0.20$ and those variables having significant $p$-value were moved into multiple logistic regression to control the influence of the confounding variables. A $95 \% \mathrm{CI}$ and the statistical significance level were determined at a p-value of $<0.05$ for all variables.

\section{Ethical Considerations}

The study was conducted after ethical approval was acquired from the College of Health Sciences of Addis Ababa University Institution Review Board (Ref. No.: 002/17/SPharma). Guidelines outlined in the Declaration of Helsinki were met. Written informed consent was also obtained from participants before collecting the required data. The study result did not intend to include participants' identifiers. The raw data were not made available to anyone, other than the research team.

\section{Results}

\section{Socio-Demographic Characteristics}

In the current study, 320 adult type 2 diabetes patients had included in the final analysis. Approximately $57 \%$ of them were female, and the majority $(52.8 \%)$ were in the age range of 50 and 65 years old with a mean age of 58 (SD, 11.2) years. Nearly $3 / 4$ th of the study participants were married and got their medication freely (Table 1).

\section{Clinical Characteristics}

In this study, about $85 \%$ of study participants had comorbidity, and $42.5 \%$ had complications. Hypertension and neuropathy were the most common comorbidity and complication, respectively (Table 2). Among study participants,

Table I Socio-Demographic Characteristics of Adult Type 2 Diabetes Patients on Follow-Up at Tikur Anbessa Specialized Hospital, Addis Ababa, Ethiopia ( $\mathrm{N}=320)$

\begin{tabular}{|c|c|c|}
\hline Variables & Categories & $\mathbf{N}(\%)$ \\
\hline Age (years) & $\begin{array}{l}\text { Mean } \pm \text { SD } \\
\leq 35 \\
35-50 \\
50-65 \\
>65\end{array}$ & $\begin{array}{l}58.1 \pm 11.2 \\
11(3.4) \\
70(21.9) \\
169(52.8) \\
70(21.9)\end{array}$ \\
\hline Sex & $\begin{array}{l}\text { Male } \\
\text { Female }\end{array}$ & $\begin{array}{l}139(43.4) \\
181(56.6)\end{array}$ \\
\hline Marital status & $\begin{array}{l}\text { Married } \\
\text { Single } \\
\text { Divorced } \\
\text { Widowed }\end{array}$ & $\begin{array}{l}250(78.1) \\
23(7.2) \\
18(5.6) \\
29(9.1)\end{array}$ \\
\hline Education & $\begin{array}{l}\text { No formal education } \\
\text { Primary }(1-8) \\
\text { Secondary }(9-12) \\
\text { College/university }\end{array}$ & $\begin{array}{l}47(14.7) \\
59(18.4) \\
97(30.3) \\
117(36.6)\end{array}$ \\
\hline Residence & $\begin{array}{l}\text { Addis Ababa } \\
\text { Out of Addis Ababa }\end{array}$ & $\begin{array}{l}278(86.9) \\
42(13.1)\end{array}$ \\
\hline Occupation & $\begin{array}{l}\text { Employed } \\
\text { Unemployed } \\
\text { Private } \\
\text { Student } \\
\text { Others* }\end{array}$ & $\begin{array}{l}85(26.6) \\
44(\mid 3.8) \\
4 I(\mid 2.8) \\
7(2.2) \\
143(44.7)\end{array}$ \\
\hline Source of med & $\begin{array}{l}\text { Buying } \\
\text { Free }\end{array}$ & $\begin{array}{l}74(23.1) \\
246(76.9)\end{array}$ \\
\hline Smoking & $\begin{array}{l}\text { Non smoker } \\
\text { X-smoker } \\
\text { Smoker }\end{array}$ & $\begin{array}{l}312(97.5) \\
3(0.9) \\
5(1.6)\end{array}$ \\
\hline Alcohol & $\begin{array}{l}\text { Yes } \\
\text { No }\end{array}$ & $\begin{array}{l}4 I(12.8) \\
279(87.2)\end{array}$ \\
\hline Physical activity & $\begin{array}{l}\text { Yes } \\
\text { No }\end{array}$ & $\begin{array}{l}274(85.6) \\
46(\mid 4.4)\end{array}$ \\
\hline
\end{tabular}

Note: *Retired.

Abbreviation: SD, standard deviation of mean. 
Table 2 Clinical Characteristics of Adult T2DM Patients on Follow-Up at Tikur Anbessa Specialized Hospital, Addis Ababa, Ethiopia $(\mathrm{N}=320)$

\begin{tabular}{|c|c|c|}
\hline Variables & Categories & $\mathbf{N}(\%)$ \\
\hline Body mass index & $\begin{array}{l}\text { Normal } \\
\text { Under weight } \\
\text { Over weight } \\
\text { Obese }\end{array}$ & $\begin{array}{l}107(33.4) \\
2(0.6) \\
91(28.4) \\
37(11.6)\end{array}$ \\
\hline Blood pressure & $\begin{array}{l}\text { Uncontrolled } \\
\text { Controlled }\end{array}$ & $\begin{array}{l}96(30.0) \\
106(33.1)\end{array}$ \\
\hline Hyperglycemia & $\begin{array}{l}\text { Yes } \\
\text { No }\end{array}$ & $\begin{array}{l}221(69.1) \\
99(30.1)\end{array}$ \\
\hline Hypoglycemia & $\begin{array}{l}\text { Yes } \\
\text { No }\end{array}$ & $\begin{array}{l}39(12.2) \\
281(87.8)\end{array}$ \\
\hline Lipid control & $\begin{array}{l}\text { Controlled } \\
\text { Poorly controlled }\end{array}$ & $\begin{array}{l}300(93.8) \\
20(6.3)\end{array}$ \\
\hline Number of comorbid & $\begin{array}{l}\text { No } \\
\mathrm{I}-2 \\
\geq 3\end{array}$ & $\begin{array}{l}48(15.0) \\
217(67.8) \\
55(17.2)\end{array}$ \\
\hline Type of comorbidity & $\begin{array}{l}\text { Hypertension } \\
\text { Dyslipidemia } \\
\text { Ischemic Heart Disease } \\
\text { Chronic Kidney Disease } \\
\text { HIV/AIDS } \\
\text { Asthma } \\
\text { Others* }\end{array}$ & $\begin{array}{l}221(69.1) \\
90(28.1) \\
50(15.6) \\
23(7.2) \\
13(4.1) \\
9(2.8) \\
91(28.4)\end{array}$ \\
\hline Number of complication & $\begin{array}{l}\text { No } \\
\mathrm{I}-2 \\
\geq 3\end{array}$ & $\begin{array}{l}184(57.5) \\
127(39.7) \\
9(2.8)\end{array}$ \\
\hline Type of complications & $\begin{array}{l}\text { Neuropathy } \\
\text { Nephropathy } \\
\text { Retinopathy } \\
\text { Diabetes foot ulcer } \\
\text { Others** }\end{array}$ & $\begin{array}{l}116(36.3) \\
26(8.1) \\
21(6.6) \\
4(1.3) \\
13(4.1)\end{array}$ \\
\hline Number of medication & $\begin{array}{l}\text { Mean } \pm \text { SD } \\
<5 \\
\geq 5\end{array}$ & $\begin{array}{l}4.97 \pm 2.05 \\
13 \mid(40.9) \\
188(58.8)\end{array}$ \\
\hline Duration of disease (years) & $\begin{array}{l}\text { Mean } \pm \text { SD } \\
<5 \\
5-10 \\
10-15 \\
\geq 15\end{array}$ & $\begin{array}{l}13.83 \pm 8.87 \\
35(10.9) \\
42(13.1) \\
51(15.9) \\
99(30.9)\end{array}$ \\
\hline
\end{tabular}

Notes: *Thyroid disorders, osteoarthritis, psychotic disorder, infection, cancer, seizure, obesity. **Peripheral arterial disease, autonomic gastroparesis; skin infection, sexual dysfunction.

Metformin + Insulin was the most utilized antidiabetes medication, while ACEIs/ARBs were the most utilized medication for other than diabetes (Figure 1).

\section{Factors Associated with Diabetes Complications}

Sociodemographic and clinical characteristics of patients were subjected to logistic regression to determine a predictor of complications in T2DM patients. From there, the number of medications taken and the duration of the disease had significantly related to the occurrence of complications in type 2 diabetes patients (Table 3). Patients who take five and above medication were more than three times $(\mathrm{AOR}=3.08,95 \% \mathrm{CI}: 1.62-5.85)$ risk of developing complications. Study participants who had a disease duration of 5-10 years $(\mathrm{AOR}=3.50,95 \% \mathrm{CI}$ : $1.19-10.28)$ and fifteen and above $(\mathrm{AOR}=3.59,95 \% \mathrm{CI}$ : 1.358-9.493) were also more than three times at risk of diabetes complication as compared to those who have below five years.

\section{Discussion}

T2DM is one of the most common metabolic diseases that have an outcome of chronic complications upon progress, which impair the wellbeing of patients, challenge the health service providing system, and increase diabetic mortality. ${ }^{11}$ In Ethiopia, the annual health expenditure to treat diabetes and prevent complications among adults (20-79 years) was estimated to range from $\$ 80-200$ million in $2015 .^{12}$ Thus, understanding the prevalence and identifying associated risk factors of type $2 \mathrm{DM}$ complication was important for improved management and prevention of the disease., 9 Therefore, the objective of this study was to determine the prevalence of chronic complications, identifying related factors, and its management practice among adult T2DM outpatients. Our data indicate that most participants in the study had comorbidity, which could raise the risk of complications. The duration of disease and the number of medications was the factor related to the occurrence of T2DM complications.

In this study, about $42 \%$ of study participants had at least one complication. This finding is consistent with other local research conducted in Wollo $(48.6 \%)^{14}$ and Jimma $(52.5 \%)^{15}$ Ethiopia, Chin $(52 \%){ }^{13}$ and Taiwan $(52.6 \%){ }^{16}$ This high prevalence of complications among T2DM patients could be associate with the advanced age of study participants (mean= $58(\mathrm{SD}, 11.2)$ ) and the presence of many comorbidities (85\%). Our findings were lower than the study conducted in the United Arab Emirates (UAE) $(83.5 \%) .{ }^{17}$ Some of the disparity realized in the occurrence of complications across different countries could also be due to differences in medical care, 


\section{Utilized medications}

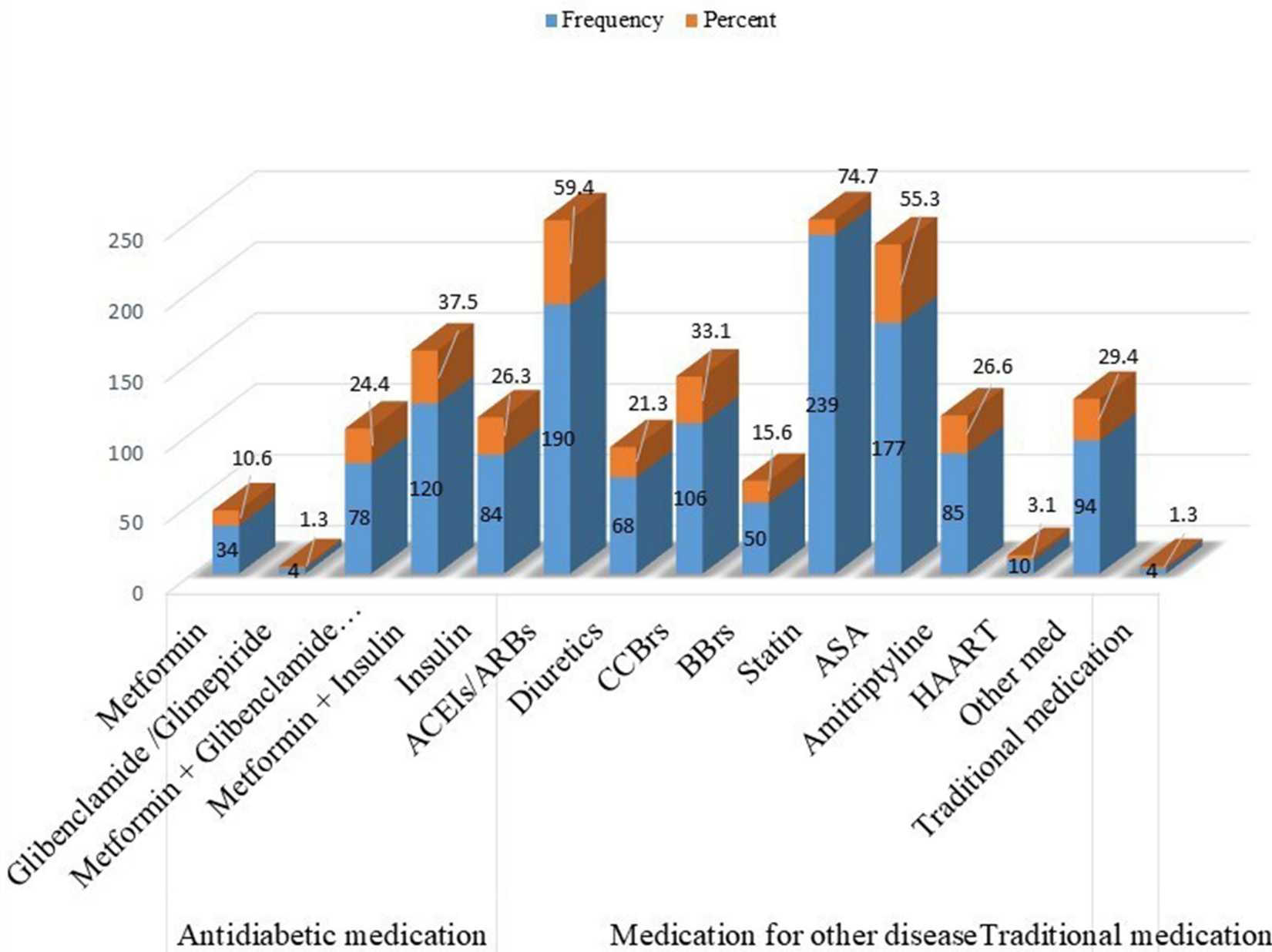

Figure I Prescribed medications among adult type 2 diabetic patients on follow-up at Tikur Anbessa Specialized Hospital, Addis Ababa, Ethiopia.

Notes: Others medication: metformin + sitagliptin, Proton pump inhibitors, carbamazepine, gabapentin, tramadol, propylthiouracil, Non-steroidal anti-inflammatory drugs. Abbreviations: ACEls/ARBs, angiotensin-converting enzyme inhibitors/angiotensin II receptor blockers; CCBrs, calcium channel blockers; BBrs, beta-blockers; HAART, highly active antiretroviral therapy.

health service resources, diagnostic guidelines applied, and definitions used in clinical practice.

Neuropathy was the most commonly reported complication that had a negative influence on the quality of life in patients with diabetes. ${ }^{11}$ In the current study neuropathy was the most common observed complication followed by nephropathy while in some studies nephropathy was the most common followed by neuropathy. ${ }^{18-20}$ In agreement with our findings, the systematic review of research conducted in North Africa showed that chronic diabetes complications prevalence ranged from $6.7 \%$ to $46.3 \%$ for nephropathy and $21.9 \%$ to $60 \%$ for neuropathy. ${ }^{21}$ Similarly, in a multinational study conducted at 28 countries in different continents such as Asia, Africa, Europe, and South America, neuropathy was the most common microvascular complication across the study regions $(25 \%$ to $83 \%){ }^{22}$

Diabetes comorbidities are also disorders that impact people with diabetes compared to those people without diabetes. ${ }^{23}$ In the current study, about $85 \%$ of study participants had at least one comorbidity. Among these, hypertension (69\%) was the most common prevalent comorbidity followed by dyslipidemia (28\%). This finding is consistent with other studies that reported hypertension as a common comorbid disease. ${ }^{9,15,17,20}$ The high proportion of hypertension, in specific, has a prominent impact on the prevalence of microvascular and macro-vascular complications. 
Table 3 Bivariate and Multivariate Analysis of Factors Associated with Diabetes Complications Among Adult T2DM Patients on Follow-Up at Tikur Anbessa Specialized Hospital, Addis Ababa, Ethiopia

\begin{tabular}{|c|c|c|c|c|c|}
\hline \multirow{2}{*}{ Variables } & \multirow[t]{2}{*}{ Categories } & \multicolumn{2}{|c|}{ Complication } & \multicolumn{2}{|c|}{ Odds Ratio $(95 \% \mathrm{Cl})$} \\
\hline & & Yes (N (\%)) & No (N (\%)) & COR & AOR \\
\hline \multirow[t]{4}{*}{ Age (years) } & $\leq 35$ & $10(3.1)$ & $\mathrm{I}(0.3)$ & 1.00 & \\
\hline & $35-50$ & $47(14.7)$ & $23(7.2)$ & $4.89(0.59-40.58)$ & $0.94(0.08-\mid I .5 I)$ \\
\hline & $50-65$ & $97(30.3)$ & $72(22.5)$ & $7.42(0.93-59.30)$ & $1.27(0.11-14.98)$ \\
\hline & $>65$ & $30(9.4)$ & $40(12.5)$ & $13.33(1.62-109.91)$ & $1.13(0.09-14.27)$ \\
\hline \multirow[t]{2}{*}{ Blood pressure } & Controlled & $53(26.2)$ & $53(26.2)$ & & \\
\hline & Uncontrolled & $55(27.2)$ & $4 I(20.3)$ & $0.75(0.43-1.30)$ & $0.69(0.33-1.44)$ \\
\hline \multirow[t]{2}{*}{ Hyperglycemic } & Yes & 127(39.7) & $94(29.4)$ & & \\
\hline & No & $57(17.8)$ & $42(13.1)$ & $1.00(0.62-1.62)$ & $0.8 I(0.36-\mid .8 I)$ \\
\hline \multirow[t]{2}{*}{ Lipid } & Controlled & $173(54.1)$ & $127(39.7)$ & & \\
\hline & Poorly controlled & $11(3.4)$ & $9(2.8)$ & $0.90(0.36-2.23)$ & $1.20(0.26-5.53)$ \\
\hline \multirow[t]{5}{*}{ Diabetes regimen } & Metformin & $27(8.4)$ & $7(2.2)$ & & \\
\hline & Glibenclamide/Glimepiride & $3(0.9)$ & $\mathrm{I}(0.3)$ & $1.29(0.12-14.33)$ & $1.03(0.07-16.48)$ \\
\hline & Metformin+ Glibenclamide/Glimepiride & $52(16.3)$ & $26(8.1)$ & $1.93(0.74-5.01)$ & $1.26(0.33-4.91)$ \\
\hline & Metformin+ Insulin & $62(19.4)$ & $58(42.6)$ & $3.61(1.46-8.92)$ & $2.83(0.74-10.88)$ \\
\hline & Insulin & $40(12.5)$ & $44(13.8)$ & $4.24(1.67-10.8 I)$ & $2.68(0.68-10.62)$ \\
\hline \multirow[t]{2}{*}{ Statins } & Yes & $124(38.8)$ & $115(35.9)$ & 1.00 & \\
\hline & No & $60(18.8)$ & $21(6.6)$ & $0.63(0.18-2.19)$ & $0.53(0.17-1.7 I)$ \\
\hline \multirow[t]{2}{*}{ Aspirin } & Yes & $94(29.4)$ & $83(25.9)$ & 1.00 & \\
\hline & No & $90(28.1)$ & $53(16.6)$ & $1.75(0.58-5.24)$ & $1.35(0.53-3.44)$ \\
\hline \multirow[t]{2}{*}{ ACEI/ARB } & Yes & $101(31.6)$ & $89(27.8)$ & 1.00 & \\
\hline & No & $83(25.9)$ & $47(14.7)$ & $0.86(0.24-3.07)$ & $1.07(0.74-3.08)$ \\
\hline \multirow[t]{2}{*}{ Number of medication } & $<5$ & $92(28.8)$ & $39(12.2)$ & 1.00 & \\
\hline & $\geq 5$ & $91(28.5)$ & $97(30.4)$ & $2.52(1.57-4.03)$ & $3.08(1.62-5.85)$ \\
\hline \multirow[t]{4}{*}{ Duration of disease (years) } & $<5$ & $28(12.3)$ & $7(3.1)$ & 1.00 & \\
\hline & $5-10$ & $2 \mathrm{I}(9.3)$ & $21(9.3)$ & $4.00(1.43-11.16)$ & $3.50(1.19-10.28)$ \\
\hline & $10-15$ & $3 I(\mid 3.7)$ & $20(8.8)$ & $2.58(0.95-7.02)$ & $2.47(0.85-7.18)$ \\
\hline & $\geq 15$ & $52(22.9)$ & $47(20.7)$ & $3.62(1.45-9.05)$ & $3.59(1.36-9.49)$ \\
\hline \multirow[t]{3}{*}{ Number of comorbidity } & No & $31(9.7)$ & $17(5.3)$ & 1.00 & \\
\hline & $1-2$ & $|3|(40.9)$ & $86(26.9)$ & $1.20(0.62-2.30)$ & $0.50(0.20-1.23)$ \\
\hline & $\geq 3$ & $22(6.9)$ & $33(10.3)$ & $2.74(1.23-6.09)$ & $\mathrm{I} .20(0.4 \mathrm{I}-3.54)$ \\
\hline
\end{tabular}

Note: Bolds: statistical significant ( $\mathrm{P}$-value $<0.05)$.

Abbreviations: AOR, adjusted odds ratio; $\mathrm{Cl}$, confidence interval; COR, crude odds ratio; ACEls/ARBs, angiotensin converting enzyme inhibitors/angiotensin II receptor blockers.

Poor glycemic control is a significant factor that contributes to the development of chronic complications related to diabetes. ${ }^{24}$ Approximately $69 \%$ of the blood glucose levels of the study participants were in the hyperglycemia range based on the standard treatment guideline reference. These require appropriate management action since sufficient metabolic management either prevents or delays the occurrence of chronic complications. ${ }^{25}$ Justification for the difficulty in attaining target blood glucose levels could include the presence of polypharmacy that affect medication adherence, fears of medication adverse effect such as dyspepsia, hypoglycemia, and weight gain, lack of access to therapy and unable to follow dietary approaches to stop hypertension (DASH).

In the current study, about $59 \%$ of study participants took five and above medication for the management of their disease condition. Regarding medications, metformin + insulin was the most utilized medication, followed by 
insulin for the management of diabetes. Metformin was the most utilized medication alone or in combination with other antidiabetic medications. It is the most recommended medication to reduce the development of chronic complications and comorbidity in diabetes patients. ${ }^{23}$

In this study, the usage of vascular preventive modality was suboptimal, including those patients with vascular complications. Our findings were consistent with a multinational study conducted in twenty-eight countries across seven geographical states (South America; North Africa, South, and East Asia, Russia, Middle East/Gulf, and China). ${ }^{22}$

In this study, the occurrence of chronic complications in T2DM patients was closely associated with the number of medications used and disease duration. For type 2 diabetes patients, polypharmacy is a common problem which is known to affect a patient's quality of life. ${ }^{26}$ In the current study, the risk of developing diabetes complications was more than three times $(\mathrm{AOR}=3.08,95 \% \mathrm{CI}$ : 1.62-5.85) in patients who took five or more medications. The current finding was consistent with the systematic review and meta-analysis that showed polypharmacy was strongly associated with the increase of all-cause mortality and macrovascular complications among type 2 diabetes patients. ${ }^{27}$

The prevalence of the identified chronic diabetes complications was also found to be positively associated with the duration of disease, regardless of the patients' age. The study participants who had disease duration of 5-10 years $(\mathrm{AOR}=3.50,95 \% \mathrm{CI}: 1.19-10.28)$ and fifteen and above years $(\mathrm{AOR}=3.59,95 \% \mathrm{CI}: 1.358-9.493)$ were more than three times at risk to develop diabetes complication compared to those who had less than five years disease duration. This finding is in agreement with the results of other studies done elsewhere. ${ }^{13,15,22,28}$

\section{Limitation}

Though the study showed important findings of chronic complications of T2DM, its risk factor, and management practice in TASH, it has its own limitations. Firstly, the cross-sectional study design could not reveal the condition of the actual patient. Secondly, the study participants were patients who had a multi-disease burden having following up in tertiary referral healthcare, resulting in an overconsideration of the actual prevalence of the diabetes complication. Therefore, it may be somewhat improper to generalize the findings of this study to the entire population of T2DM patients.

\section{Conclusion}

The prevalence of complications among T2DM patients was found to be high in TASH. The number of medications and the duration of the disease was strongly associated with the development of chronic diabetes complications. Vascular preventive regimen in patients with or without complication is suboptimal in the current study. Appropriate actions should be taken to build up medical therapy and lifestyle management to overcome amendable risk factors for complications in order to reduce morbidity and mortality.

\section{Acknowledgment}

The authors would like to thank all the data collectors, participants, nurses, and other staff of the diabetes clinic of TASH. We also like to thank all who were involved in facilitating the research activity and providing their realistic comments.

\section{Author Contributions}

Both authors contributed significantly to the reported work, in the concept and design of the research, execution, data collection, analysis, and interpretation; engaged in the drafting, revision or critical review of the paper; gave final approval of the version to be published; agreed on the journal to which the paper was submitted and to take responsibility and accountability for the contents of the article.

\section{Funding}

There is no funding to report.

\section{Disclosure}

There is no conflict of interest to be disclosed by the authors.

\section{References}

1. American Diabetes Association. Classification and diagnosis of diabetes: standards of medical care in diabetes-2018. Diabetes Care 2018;41(Supplement 1):S13-S27. doi:10.2337/dc18-S002

2. World Health Organization. Global report on diabetes: executive summary. World Health Organization, 2016. Available from: https:// apps.who.int/iris/handle/10665/204874. Accessed October 20, 2020.

3. International Diabetes Federation. IDF Diabetes Atlas. 8thed Brussels, Belgium: International Diabetes Federation; 2017. Available from: http://www. idf.org/diabetesatlas. Accessed May 30, 2020.

4. Zheng Y, Ley SH, Hu FB. Global aetiology and epidemiology of type 2 diabetes mellitus and its complications. Nat Rev Endocrinol. 2018;14 (2):88-98. doi:10.1038/nrendo.2017.151 
5. Goyal A, Gupta Y, Singla R, Kalra S, Tandon N. American diabetes association disclosures: standards of medical care in diabetes-2020. Diabetes Care. 2020;3(supplement1):S1-S212.

6. Ozougwu JC, Obimba KC, Belonwu CD, et al. The pathogenesis and pathophysiology of type 1 and type 2 diabetes mellitus. J Physiol Pathophysiol. 2013;4(4):46-57. doi:10.5897/JPAP2013.0001

7. Chawla A, Chawla R, Jaggi S. Microvascular and macrovascular complications in diabetes mellitus: distinct or continuum? Indian J Endocrinol Metab. 2016;20(4):546. doi:10.4103/2230-8210.183480

8. Wu Y, Ding Y, Tanaka Y, et al. Risk factors contributing to type 2 diabetes and recent advances in the treatment and prevention. Int J Med Sci. 2014;11(11):1185-1200. doi:10.7150/ijms.10001

9. Ekoru K, Doumatey A, Bentley AR, et al. Type 2 diabetes complications and comorbidity in Sub-Saharan Africans. E Clini Medici. 2019;16:30-41. doi:10.1016/j.eclinm.2019.09.001

10. Korsa AT, Genemo ES, Bayisa HG, et al. Diabetes mellitus complications and associated factors among adult diabetic patients in selected hospitals of West Ethiopia. Open Cardiovas Med J. 2019;13(1):41-48. doi:10.2174/1874192401913010041

11. Younis BB, Arshad R, Yousuf H, et al. Impact of type 2 diabetes mellitus on quality of life in people with diabetes presenting to a specialist diabetes clinic. Turk J Med Sci. 2017;47(1):123-126. doi:10.3906/sag-1508-3

12. International Diabetes Federation. IDF Diabetes Atlas. 7thed. Brussels, Belgium: International Diabetes Federation; 2015. Available from http://www. idf.org/diabetesatlas. Accessed June 13, 2020.

13. Liu Z, Fu C, Wang W, et al. Prevalence of chronic complications of type 2 diabetes mellitus in outpatients-a cross-sectional hospital based survey in urban China. Health Qual Life Outcomes. 2010;8 (1):62. doi:10.1186/1477-7525-8-62

14. Abejew AA, Belay AZ, Kerie MW. Diabetic complications among adult diabetic patients of a tertiary hospital in northeast Ethiopia. Adv Public Health. 2015. doi:10.1155/2015/290920

15. Worku D, Hamza L, Woldemichael K. Patterns of diabetic complications at Jimma University Specialized Hospital, Southwest Ethiopia. Ethiop J Health Sci. 2010;20(1):33-39. doi:10.4314/ejhs.v20i1.69424

16. Chen GD, Huang CN, Yang YS, et al. Patient perception of understanding health education and instructions has moderating effect on glycemic control. BMC Public Health. 2014;14:683. doi:10.1186/ 1471-2458-14-683

17. Jelinek HF, Osman WM, Khandoker AH, et al. Clinical profiles, comorbidities and complications of type 2 diabetes mellitus in patients from United Arab Emirates. BMJ Open Diabetes Res Care. 2017;5:1. doi:10.1136/bmjdrc-2017-000427
18. Wani FA, Koul RK, Raina AA, et al. Prevalence of microvascular complications in newly diagnosed type-2 diabetes mellitus. Int $J$ Sci Study. 2016;3(10):102-105. doi:10.17354/ijss/2016/21

19. Salvotelli L, Stoico V, Perrone F, et al. Prevalence of neuropathy in type 2 diabetic patients and its association with other diabetes complications: the verona diabetic foot screening program. J Diabetes Complications. 2015;29(8):1066-1070. doi:10.1016/j.jdiacomp.2015. 06.014

20. Awadalla H, Noor SK, Elmadhoun WM, et al. Diabetes complications in Sudanese individuals with type 2 diabetes: overlooked problems in sub-Saharan Africa? Diabetes Metab Syndr. 2017;11 (supplement2):S1047-S1051. doi:10.1016/j.dsx.2017.07.039

21. Bos M, Agyemang C. Prevalence and complications of diabetes mellitus in Northern Africa, a systematic review. BMC Public Health. 2013;13:387. doi:10.1186/1471-2458-13-387

22. Litwak L, Goh SY, Hussein Z, et al. Prevalence of diabetes complications in people with type 2 diabetes mellitus and its association with baseline characteristics in the multinational Alchieve study. Diabetol Metab Syndr. 2013;5(1):57. doi:10.1186/1758-5996-5-57

23. American Diabetes Association. Standards of medical care in diabetes-2018 abridged for primary care providers. Clin Diabetes. 2018;36(1):14-37. doi:10.2337/cd17-0119

24. Stolar M. Glycemic control and complications in type 2 diabetes mellitus. Am J Med. 2010;123(supplement3):S3-S11. doi:10.1016/j. amjmed.2009.12.004

25. Nathan DM and DCCT/EDIC Research Group. The diabetes control and complications trial/epidemiology of diabetes interventions and complications study at 30 years: overview. Diabetes Care. 2014;37 (1):9-16. doi:10.2337/dc13-2112

26. Dobrică EC, Găman MA, Cozma MA, et al. Polypharmacy in type 2 diabetes mellitus: insights from an internal medicine department. Medicina (Kaunas). 2019;55(8):436. doi:10.3390/medicina55080436

27. Labib A-M, Martins AP, Raposo JF, et al. The association between polypharmacy and adverse health consequences in elderly type 2 diabetes mellitus patients; a systematic review and meta-analysis. Diabetes Res Clin Pract. 2019;155:107804. doi:10.1016/j.diabres. 2019.107804

28. Fereidony M, Shoghiyan-davar M, Bigane O, Bashiri Y, DehghaniArani M, Bagheri N. Investigating factors associated with diabetes complications among type 2 diabetic patients. J Res Med Dent Sci. 2018;6(3):301-306. doi:10.24896/jrmds.20186346

\section{Publish your work in this journal}

Diabetes, Metabolic Syndrome and Obesity: Targets and Therapy is an international, peer-reviewed open-access journal committed to the rapid publication of the latest laboratory and clinical findings in the fields of diabetes, metabolic syndrome and obesity research. Original research, review, case reports, hypothesis formation, expert opinion and commentaries are all considered for publication. The manuscript management system is completely online and includes a very quick and fair peer-review system, which is all easy to use. Visit http://www.dovepress.com/testimonials.php to read real quotes from published authors. 